\title{
Atmospheric Levels of Formaldehyde and Acetaldehyde and their Relationship with the Vehicular Fleet Composition in Salvador, Bahia, Brazil
}

\author{
Jailson B. de Andrade*, Marta V. Andrade ${ }^{+,}$and Heloisa L.C. Pinheiro ${ }^{++}$ \\ Instituto de Química, UFBA, Campus de Ondina, 40.170.290 Salvador - Ba, Brazil
}

Received: February 26, 1998

\begin{abstract}
O presente trabalho enfoca os níveis de formaldeído e acetaldeído em fase gasosa e a sua correlação com a frota veicular, em vários locais em Salvador, BA, Brasil. As amostras foram coletadas utilizando cartuchos Sep Pak C18 impregnados com uma solução ácida de 2,4-dinitrofenilidrazina (DNPH). As hidrazonas resultantes foram separadas e quantificadas através de cromatografia líquida de alta eficiência. As amostras foram coletadas durante períodos de $1-2 \mathrm{~h}$ em seis locais na cidade de Salvador, Bahia: em uma estação de ônibus, no interior de um túnel, no estacionamento fechado de um shopping center, no estacionamento fechado de um prédio comercial, em um bairro residencial e em um bairro comercial; e em dois outros locais distantes de Salvador: Cacha Pregos e Lagoa Verde. As concentrações medidas de formaldeído e acetaldeído, estiveram, respectivamente, na faixa de $0,20-88 \mathrm{ppbV}$ and 0,40 - $93 \mathrm{ppbV}$. A relação das concentrações formaldeído/acetaldeído determinadas nesses locais foram: 0,66 (estacionamento do shopping center); 0,65 (estacionamento do prédio comercial); 4,4 (estação de ônibus); 1,2 (túnel); 1,0 (bairro residencial) 1,7 (bairro comercial), 1,1 (Cacha Pregos) e 0,8 (Lagoa Verde). No caso do túnel, este representa a frota total da cidade. Contagens de tráfego, realizadas durante o período de amostragem, revelaram que $82 \%$ dos veículos que passaram pelo local eram leves e $18 \%$ veículos pesados (diesel). Um cálculo simples utilizando a composição da frota no túnel e a relação formaldeído/acetaldeído na estação de ônibus (como a assinatura dos veículos a diesel) e nos estacionamentos fechados (como a assinatura dos veículos leves), revelou uma relação formaldeído/acetaldeído igual a 1,3 a qual é muito próxima do valor medido 1,2. De forma idêntica, os valores calculados para os bairros comercial e residencial foram, respectivamente 1,7 e 0,62. Isto nos permite concluir que os níveis atmosféricos de formaldeído e acetaldeído em Salvador apresentam uma correlação com a composição da frota veicular.
\end{abstract}

The present work is concerned with the formaldehyde and acetaldehyde content in the gas-phase and their concentrations correlation, with the vehicular fleet, at several sites in Salvador, BA, Brazil. The samples were collected using C-18 Sep Pak cartridges coated with an acidic solution of 2,4-dinitrophenylhydrazine (DNPH). The resulting hydrazones were separated and quantified using HPLC. Samples were collected during 1 - $2 \mathrm{~h}$ periods at six sites located in the city of Salvador, Bahia: a bus station, a tunnel, a commercial mall parking lot, a business building parking lot a residential district and a commercial district; and at two other sites far from Salvador: Cacha Pregos and Lagoa Verde. The measured concentrations for formaldehyde and acetaldehyde ranged, respectively, from 0.20 to $88 \mathrm{ppbV}$ and from 0.40 to $93 \mathrm{ppbV}$. The formaldehyde/acetaldehyde concentration ratio determined in these sites were: 0.66 (commercial mall parking lot); 0.65 (business building parking lot); 4.4 (bus station); 1.2 (tunnel); 1.0 (residential area), 1.7 (commercial area), 1.1 (Cacha Pregos) and 0.8 (Lagoa Verde). In the case of the tunnel, it represents the hole vehicular fleet of the city. Traffic counts taken during the sampling periods indicated that $82 \%$ of the vehicles at that site were light duty engines and $18 \%$ were heavy duty vehicles. A simple calculation using the tunnel fleet composition and the ratio formaldehyde/acetaldehyde at the bus station (as a diesel signature) and at the parking (as a light duty vehicles signature) revealed an expected tunnel ratio of 1.3 which is very close to the measured ratio 1.2. Indeed, the expected ratio for both the commercial area and residential area was, respectively, 1.7 and 0.62 . It allows us to conclude that

*To whom correspondence should be addressed jailsong@ufba.br +Present address: Universidade do Estado da Bahia, UNEB, Estrada das Barreiras S/N, 40.000, Salvador, Bahia - Brazil

++Centro Federal de Educação Tecnológica da Bahia- CEFET 
the atmospheric level of formaldehyde and acetaldehyde in Salvador has a close relationship with the vehicular fleet composition.

Keywords: formaldehyde, acetaldehyde, carbonyl, alcohol-fueled vehicles

\section{Introduction}

Aldehyde sources in the atmosphere include primary emissions from natural vegetation, industrial plants, incinerators and automobiles, as well as secondary ones via photo-oxidation of methane, isoprene, and other biogenic and anthropogenic hydrocarbons ${ }^{1}$. The two most abundant aldehydes in ambient air are formaldehyde and acetaldehyde $^{1}$. They are of great significance to atmospheric chemistry due to the strong influence these species have on photochemical reactions that lead to the formation of important smog components such as nitric acid, peroxiacetylnitrate (PAN), and several others ${ }^{1-3}$.

In the past decade a substantial amount of information on surface atmospheric levels of formaldehyde and acetaldehyde has been generated ${ }^{2-14}$. However, most of the knowledge about formaldehyde and, principally, of acetaldehyde in the atmosphere comes from measurements in countries where the vehicular fleet is fueled with gasoline and diesel. In this way, information of aldehyde levels, emitted in countries, as is the case in Brazil, where ethanol is used as a fuel and also added to gasoline, as an octane booster (gasohol, gasoline with $18 \%$ to $22 \%$ v/v ethyl alcohol) are needed for a more complete description of their atmospheric budgets.

The present work is concerned with the determination of formaldehyde and acetaldehyde in closed places and in the atmosphere at a tropical region strongly affected by sea breezes due to the use of ethanol, gasohol and diesel as a fuel.

\section{Experimental}

\section{Site description}

The metropolitan area of Salvador is located on the Atlantic coast of Brazil at $13^{\circ} 01^{\prime} \mathrm{S}$ and $38^{\circ} 31^{\prime} \mathrm{W}$, with about 2.2 million inhabitants distributed over a $324 \mathrm{~km}^{2}$ area. Salvador is a tropical city with yearly average maximum and minimum temperatures of $32^{\circ} \mathrm{C}$ and $19{ }^{\circ} \mathrm{C}$, respectively. The samples were collected at eight sites:

i) at a bus station which corresponds to an area of ca. $13,920 \mathrm{~m}^{2}$. The predominant traffic is diesel fueled buses which could rise the rate of $150 \mathrm{bus} / \mathrm{h}$ in rush time. During four days one hour samples, from 8 am to $9 \mathrm{pm}$, were collected. During the collection period the temperature varied between $27^{\circ} \mathrm{C}$ and $30^{\circ} \mathrm{C}$;

ii) at a tunnel which is $300 \mathrm{~m}$ long, and carries four lanes of traffic, two in each direction. It is representative of the vehicle fleet of Salvador because the traffic includes light duty vehicles (average rate 1980 vehicles/hour) which use both hydrous ethanol and gasohol (18-22\% ethanol v/v in gasoline) as well as diesel fueled heavy duty vehicles (average rate 420 vehicles/hour). During the collection period the vehicular fleet of Salvador was composed by $41.2 \%$ of ethanol fueled vehicles, $49.8 \%$ of gasohol fueled vehicles, $8.3 \%$ of diesel fueled vehicles and $0.7 \%$ of other fuels and the temperature varied between $29^{\circ} \mathrm{C}$ and $31^{\circ} \mathrm{C}$;

iii) at a commercial mall parking lot (indoor), in which the predominant traffic is light duty vehicles fueled with gasohol or ethanol;

iv) at a business building parking lot (indoor), in which the predominant traffic is light duty vehicles fueled with gasohol or ethanol. The ventilation system in this place was worse than that at a commercial mall parking lot

v) Rio Vermelho district, typical of many in Salvador, is located in a residential neighborhood, at a beach site, where the predominant traffic is light duty vehicles;

vi) Baixa dos Sapateiros district, is located in a commercial neighborhood, where the predominant traffic is diesel fueled buses;

vii) Cacha Pregos site, is located on Itaparica Island, $20 \mathrm{~km}$ from Salvador, it is a fishing village; and

viii) Lagoa Verde site, is located in a rural area, $250 \mathrm{~km}$ from Salvador

\section{Reagent preparation}

The DNPH solution was prepared initially $0.1 \%$ in acetonitrile/CCl$/ \mathrm{CH}_{3} \mathrm{PO}_{4} 85 / 14 / 1$ (v/v/v). The solution was then purified by one back extraction with water and diluted to be $0.05 \%$ DNPH in acetonitrile $/ \mathrm{H}_{2} \mathrm{O} / \mathrm{H}_{3} \mathrm{PO}_{4} 30 / 69 / 1$ $(\mathrm{v} / \mathrm{v} / \mathrm{v})$. It was stored in a $2.5 \mathrm{~L}$ amber glass bottle containing $200 \mathrm{~mL}$ of $\mathrm{CCl}_{4}$ and a Teflon coated magnetic stirring bar. The blank levels of formaldehyde and acetaldehyde were under $20 \mathrm{nmol} / \mathrm{L}$. A more detailed account of reagent preparation can be found elsewhere ${ }^{2,15}$.

\section{Preparation of the SEP PAK C18 cartridges}

Prior to the use the cartridges were washed with $2 \mathrm{~mL}$ of methanol and $2 \mathrm{~mL}$ of acetonitrile. $3.0 \mathrm{~mL}$ of purified DNPH solution was pulled through the cartridges from the glass bottle. Excess of liquid was blow out of the cartridges with carbonyl free nitrogen. The cartridges were then wrapped in aluminum foil and dried in a dessicator and then storad in a refrigerator. 


\section{Sampling and analytical methods}

Ambient air was pulled through the coated cartridges at 1.0 L/min, during $1-2 \mathrm{~h}$. The cartridge samplers were located approximately $1.7 \mathrm{~m}$ above the ground. Whilst, at the Rio Vermelho site it was located approximately $9 \mathrm{~m}$ above the ground (outside the third floor of a residential building) and at Baixa dos Sapateiros site it was located approximately $4 \mathrm{~m}$ above the ground (outside the first floor of a commercial building). After sampling the cartridges were eluted with $5 \mathrm{~mL}$ of acetonitrile and aliquots of $10 \mu \mathrm{L}$ of the liquid phase were injected directly into the HPLC system.

A Varian liquid chromatograph (model 2510) equipped with a Rheodyne injector and a variable UV/VIS detector (model 2550) at $365 \mathrm{~nm}$ and 0.02 - 1.28 AUFS was used. The analytical column used was Econosphere C18 $5 \mu \mathrm{m}$, $250 \mathrm{~mm}$ x $4.6 \mathrm{~mm}$ i.d. (Alltech). The mobile phase was acetonitrile:water $(57: 43 \mathrm{v} / \mathrm{v})$ at $1.0 \mathrm{~mL} / \mathrm{min}$. A more detailed account of the analytical procedures can be found elsewhere $^{16}$. The detection limit of the HPLC method ( $\mathrm{S} / \mathrm{N}=3$ based on peak height) was $0.1 \mathrm{ppbV}$ and $0.05 \mathrm{ppbV}$ for formaldehyde and acetaldehyde, respectively, in $120 \mathrm{~L}$ of air sampled.

\section{Results and Discussion}

In metropolitan areas, vehicular emissions are important and possibly, at times, the predominant contributors to aldehydes, hydrocarbons and aerosols $s^{1,17,18}$. The aldehyde concentrations in exhaust funes of various automobiles fueled with gasoline have been reported by the $\mathrm{NRC}^{1}$ and formaldehyde is almost always the predominant aldehyde emitted by automobiles powered by gasoline with and without catalytic converters ${ }^{1}$. In the case of ethanol fueled vehicles the acetaldehyde concentrations emitted are significantly higher than formaldehyde ${ }^{19,20}$. The four enclosed sites: bus station; commercial mall parking lot; business building parking lot and tunnel were affected, mainly, by primary sources where the vehicular emissions are predominant. In the bus station the bus fleet, fueled by diesel, was predominant; at the commercial mall parking lot and at the business building parking lot the light duty vehicles, fueled by both ethanol and gasohol were prevalent; the tunnel is representative of the fleet of Salvador city.

At the bus station the formaldehyde concentrations are significantly higher than acetaldehyde (Figure 1). On average, for eleven samples collected on two different days, the ratio formaldehyde / acetaldehyde was $4.40 \pm 0.89$ (Table 1). The highest formaldehyde and acetaldehyde concentrations measured were, respectively $76 \mathrm{ppbV}$ and $16 \mathrm{ppbV}$.

At the commercial mall parking lot acetaldehyde concentrations are higher than formaldehyde (Fig. 1). On average, for five samples collected, the ratio formaldehyde /

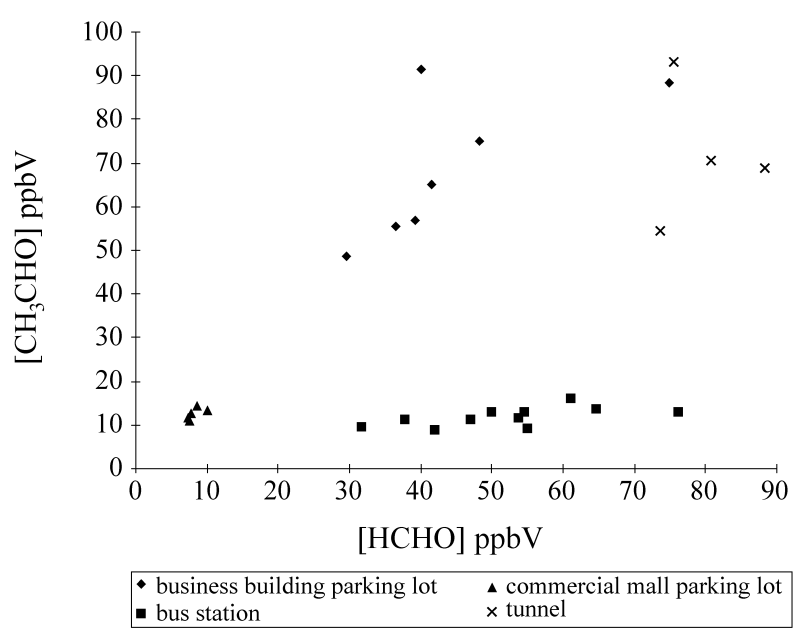

Figure 1. Formaldehyde and acetaldehyde concentrations at four closed sites: bus station; commercial mall parking lot; business building parking lot and tunnel.

Table 1. Formaldehyde and Acetaldehyde concentrations at several sites.

\begin{tabular}{|c|c|c|c|c|c|c|c|}
\hline Site & $\mathrm{N}$ & {$[\mathrm{HCHO}]_{\min }$} & {$[\mathrm{HCHO}]_{\max }$} & {$[\mathrm{HCHO}]_{\mathrm{av}}$} & {$\left[\mathrm{CH}_{3} \mathrm{CHO}\right]_{\min }$} & {$\left[\mathrm{CH}_{3} \mathrm{CHO}\right]_{\max }$} & {$\left[\mathrm{CH}_{3} \mathrm{CHO}\right]_{\mathrm{av}}$} \\
\hline Bus station & 11 & 31 & 76 & 52 & 8.8 & 16 & 12 \\
\hline $\begin{array}{l}\text { Commercial Mall } \\
\text { Parking lot }\end{array}$ & 5 & 7.4 & 10 & 8.3 & 11 & 14 & 13 \\
\hline $\begin{array}{l}\text { Business Building } \\
\text { Parking lot }\end{array}$ & 7 & 30 & 75 & 44 & 49 & 91 & 69 \\
\hline Tunnel & 4 & 74 & 88 & 80 & 55 & 93 & 72 \\
\hline Residential area & 17 & 1.3 & 4.1 & 2.9 & 0.60 & 6.9 & 3.5 \\
\hline Commercial area & 24 & 4.3 & 16 & 11 & 3.0 & 15 & 6.3 \\
\hline Lagoa Verde & 17 & 0.20 & 4.6 & 1.5 & 0.50 & 5.9 & 2.1 \\
\hline Cacha-Pregos & 20 & 0.20 & 2.5 & 1.2 & 0.40 & 2.3 & 1.2 \\
\hline
\end{tabular}

$\mathrm{N}=$ number of samples

min. $=$ minimum $; \max .=$ maximum $;$ av.$=$ average . 
acetaldehyde was $0.66 \pm 0.07$ (Table 1). The highest formaldehyde and acetaldehyde concentrations measured were, respectively $10 \mathrm{ppbV}$ and $14 \mathrm{ppbV}$. At the business building parking lot the aldehyde concentrations were about five times higher (Fig. 1) but, on average, for seven samples collected, the ratio formaldehyde / acetaldehyde were close $(0.65 \pm 0.12)$ to that measured at the commercial mall parking lot.

In the case of the tunnel (Fig. 1), on average, for four samples collected, the ratio formaldehyde / acetaldehyde was $1.2 \pm 0.24$. The highest formaldehyde and acetaldehyde (Table 1) concentrations measured were, respectively $88 \mathrm{ppbV}$ and $93 \mathrm{ppbV}$. Traffic counts taken during the sampling periods indicated that $82 \%$ of the vehicles at the site were light duty engines and $18 \%$ were heavy duty vehicles. A simple calculation (see appendix A) using the tunnel fleet composition and the ratio formaldehyde/acetaldehyde at the bus station (as a diesel signature) and at the parking (as a light duty vehicles signature) revealed an expected tunnel ratio of 1.3 which is very closed to the measured ratio 1.2 (Table 1).

In the case of the commercial area, in which the predominant traffic is diesel fueled buses, formaldehyde, in all samples collected, was the major carbonyl compound observed (Fig. 2). On average, for twenty four samples collected during five days, the ratio formaldehyde / acetaldehyde was $1.8 \pm 0.48$ (Table 1). Indeed, using traffic counts done during the sampling period, the expected ratio for this site was 1.7. For the residential area, in which the predominant traffic is light duty vehicles the predominant carbonyl was acetaldehyde (Fig. 2). On average, for seventeen samples collected during four days, the ratio formaldehyde / acetaldehyde was $1.0 \pm 0.51$ (Table 1). In the same way, the calculations revealed an expected formaldehyde/acetaldehyde ratio of 0.62 to this site. For comparison, formaldehyde and acetaldehyde were measured in two other sites far from Salvador, Cacha Pregos and Lagoa Verde, where the atmosphere is not subject to influences from traffic. No relationship between the formaldehyde /

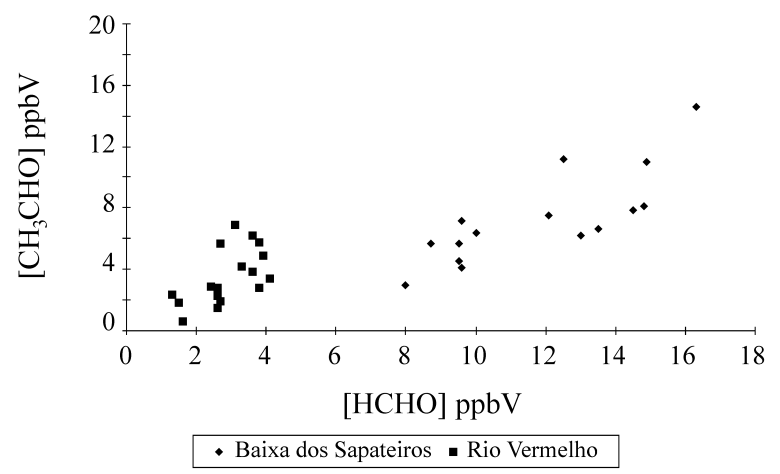

Figure 2. Formaldehyde and acetaldehyde concentrations at two urban sites: a commercial district and a residential district.

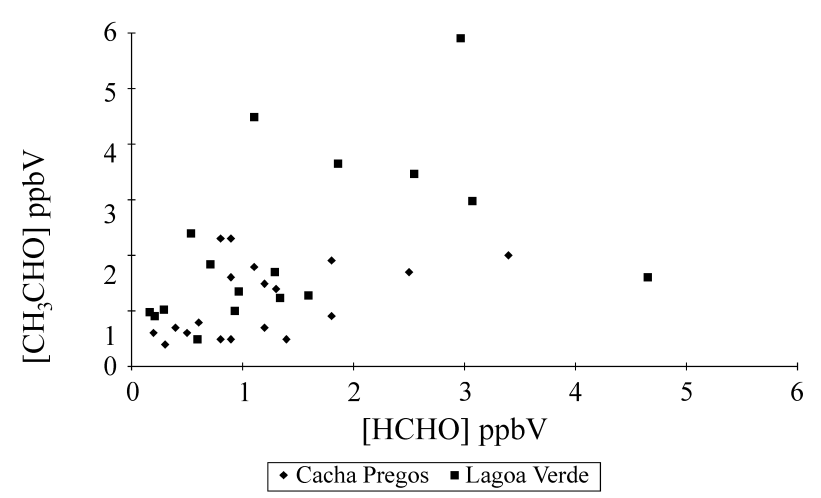

Figure 3. Formaldehyde and acetaldehyde concentrations at a fishing village and a rural area.

acetaldehyde ratios was observed (Fig. 3). It allows us to conclude that the atmospheric level of formaldehyde and acetaldehyde in Salvador has a close relationship to the vehicular fleet composition, as by using traffic counts and the signatures for both diesel and light duty vehicles it is possible to estimate the local formaldehyde/acetaldehyde ratio.

\section{Conclusions}

The atmospheric levels of formaldehyde and acetaldehyde in Salvador have a close relationship with the vehicular fleet composition. We do not have data for ambient levels of carbonyl compounds prior to the introduction of ethanol and gasohol as a vehicle fuel in Brazil. Meanwhile, our study suggests a close relationship between ambient acetaldehyde levels and ethanol use as a vehicle fuel.

\section{Acknowledgments}

This work was supported by the National Research Council of Brazil (CNPq). The authors thank Anselmo Elcana de Oliveira and Dr. José Oscar Nogueira Reis for useful discussions. H.L.C.P is supported by a CAPES fellowship and M.V.A. is supported by a CNPq fellowship

\section{Appendix A}

Traffic counts taken during the sampling periods, into the tunnel, indicated that $82 \%$ of the vehicles at that site were light duty engines and $18 \%$ were heavy duty vehicles. The formaldehyde/acetaldehyde ratio at the parking, which was used as a light duty vehicles signature, was 0.65 . On the other hand, the formaldehyde/acetaldehyde ratio at the bus station, which was used as a diesel signature, was 4.4. Then, the expected formaldehyde/acetaldehyde ratio (ER) inside the tunnel is: $\mathrm{ER}=0.82 \times 0.65+0.18 \times 4.4=1.3$.

\section{References}

1. Formaldehyde and Other Aldehydes, National Research Council, Committee on Aldehydes, Chapter 5, 
National Academy of Science Press, Washington, DC. 1981.

2. de Andrade, J.B.; Pinheiro, H.L.C.; Andrade, M.V. J. Braz. Chem. Soc. 1995, 3, 287.

3. Tanner, R.L.; Miguel, A.H.; de Andrade, J.B.; Gaffney, J.S.; Streit, G.E. Environ. Sci. Technol. 1988, 22, 1026.

4. Grosjean, D. Environ. Sci. Technol. 1982, 16, 254.

5. Tanner, R.L.; Meng, Z. Environ. Sci. Technol. 1984, $18,723$.

6. Salas, L.J.; Singh, L.J. Atmos. Environ. 1986, 20, 1301.

7. Carlier, P.; Hannachi, H.; Mouvier, G. Atmos. Environ. 1986, 20, 2079.

8. Harris, G.W.; MacKay, G.I.; Iguchi, T.; Mayne, G.I.; Schiff, H.I. J. Atmos. Chem. 1989, 8, 119.

9. Grosjean, D.; Miguel A.H.; Tavares, T.M. Atmos. Environ. 1990, 24, 106.

10. Stasumabayashi, H.; Kurita, H.; Chang, Y.; Carmichael, G.R.; Ueda, H. Atmos. Environ. 1995, 29, 255.
11. Yokouchi, Y.; Mukai, H.; Nakajima, K.; Ambe, Y. Atmos. Environ. 1990, 24A, 439.

12. Schulam, P.; Newbold, R.; Hull, L. A. Atmos. Environ. 1985, 19, 623.

13. Grosjean, E.; Williams II, E.L.; Grosjean, D. J. Air Waste Manage. Assoc. 1993, 43, 469.

14. de Andrade, J.B.; Tanner, R.L. Atmos. Environ. 1992 , $26 A, 825$.

15. de Andrade, J.B.; Pinheiro, H.L.C.; Andrade, M.V. Quím. Anal. 1996, 15, 144.

16. de Andrade, J.B.; Pinheiro, H.L.C.; Andrade, M.V. Intern. J. Environ. Anal. Chem. 1993, 52, 56.

17. de Andrade, J.B.; Macedo, M.A.; Korn, M.; Oliveira, E.; Gennari, M.A. Toxicol. and Envir. Chem. 1996, 54, 23.

18. Miguel, A.H. Environ. Sci. Technol. 1991, 25, 590.

19. de Andrade, J.B.; Miguel, A.H. Intern. J. Environ. Anal. Chem. 1985, 21, 229.

20. Miguel, A.H.; de Andrade, J.B. J. Braz. Chem. Soc. 1990, $1,127$. 